Christian Political Participation in the Arab World

\author{
Dr Fiona McCallum \\ School of International Relations \\ Arts Faculty Building \\ University of St Andrews \\ St Andrews \\ Fife, KY16 9AX \\ Scotland \\ fm25@st-andrews.ac.uk
}

Dr Fiona McCallum is RCUK Academic Fellow in Religion and Politics in the School of International Relations at the University of St Andrews, Scotland. 


\title{
Christian Political Participation in the Arab World
}

\begin{abstract}
The political participation of Christians in the Arab world highlights the difficulties in reconciling the principles of equality and full rights based on citizenship with maintaining the public role of the religion of the majority of the population - Islam. Christian strategies have focused upon both Arab and state nationalism as well as pursuing individual ambitions. The political context of these efforts is also significant. Firstly, Christians are not immune to the political environment in the region which has been characterised by a tradition of authoritarianism and limited political opportunities. Secondly, the Islamic environment provides the framework for discussing the political role of non-Muslims in Muslim-majority states. Christian political participation has also been shaped by the strategies pursued by the ruling regimes. These are namely being treated as same/indistinct, the notion of 'loyal' citizens and the institutionalization of differences through quotas. Yet irrespective of what strategy is employed, religious identity continues to be the crucial factor in determining the type of political participation accessed by Christians in the region, thus challenging the notion of national unity.
\end{abstract}

\section{Introduction}

If political participation whether in the shape of voting or holding office is perceived as a sign of national and political integration of a specific community within a state, then Christians in the Arab world would appear to be fully engaged in the political process throughout the region. From champions of independence to Foreign Ministers, army generals to ideologues and government advisors to leaders of radical leftist groups, examples abound of Christian involvement in all aspects of societal and political life in the region. Yet does a list of names, however long and illustrious, quell the oft-voiced concerns regarding the equality and political opportunity of nonMuslims in Muslim-majority countries? The growth of Arab nationalism from the late nineteenth century appeared to offer Christians a chance to partake in the struggle for independence as equal citizens beside Muslims. This optimism faded with the failures of the post-colonial Arab governments. Fears over Islamic views on the position of minorities increased with the rising Islamization experienced in the region, particularly from the 1970 s onwards. While Christians may still continue to be present in cabinets and parliaments in the Middle East today, there is a danger that both Christians and Muslims will start to perceive these individuals solely as "window dressing' and masking a situation where Christians are unable to contribute to their own society without significant assistance from those in authority. However, the difficulties facing Christians in gaining access to power cannot be seen in isolation from the general political situation in the region. The Middle East political system has been characterised by authoritarian regimes with limited pluralism. It is in this context that all individuals who wish to participate in politics must operate.

This paper will examine the various strategies used by Christians to achieve this objective. For the purpose of this discussion, political participation will be taken as covering three main areas. Firstly, it refers to electoral representation where individuals are nominated, receive votes and gain seats in parliamentary and local elections. Secondly, it includes presence in ministerial cabinets (usually picked by the head of state and/or Prime Minister) where more decision-making takes place. 
Lastly, it relates to the involvement of ordinary citizens in the political process through voting in various levels of elections. As citizens, Christians like Muslims would expect to participate freely in all three categories. The factors which hinder participation of any individual will be examined, followed by further constraints experienced by Christians due to the Islamic environment prevalent in most countries in the Arab world. The paper will then provide an overview of the different methods of political participation practised by Christians in the Middle East, namely through the use of nationalism whether pan-Arab or state-centric. Regime responses to these efforts have varied and will be analysed with reference to the following categories same/indistinct citizens, 'loyal' citizens and citizens with differences institutionalised. Case studies will be taken from several countries but will be limited to those in the Arab Middle East with indigenous Christian populations. In examining the political participation of Christians, the paper will highlight the tension between the rhetoric of equality and national unity and the reality of Christian political participation, suggesting that difference based on religious identity is reinforced through regime strategies.

\section{Background to the Christian Presence and Identity in the Middle East}

The Middle East is the birthplace of the three monotheistic faiths - Judaism, Christianity and Islam. While Muslims are by far the majority of the population in the region, Jewish and Christian communities are still present. Initially, the early Christian church was persecuted under the Roman Empire but this changed once it became the official state religion in the fourth century. Theological disputes hindered the unity of the church leading to the establishment of various denominations. Resistance to the creed imposed by the Byzantine authorities was strongest on the periphery of the empire such as Egypt and Syria (Maila 1998:31). The dominant group in each area whether Orthodox or another denomination aimed to consolidate their position by attacking believers of other branches of the Christian church. It was during this period of turmoil and disunity that the third monotheistic faith - Islam was established in Arabia and the followers of Prophet Mohammed under his successors were able to conquer the entire region by the early seventh century. The Arab conquest drastically changed the environment for the Christian population in the Middle East. While some groups had been subject to Byzantine military campaigns against them, the new rulers no longer shared the same faith as their subjects. The people in the newly conquered lands were given three choices by the incoming Muslim forces. They could convert to this new religion, pay a monetary tribute (jizya) in exchange for freedom to worship and internal autonomy or continue to fight (Courbage and Fargues 1994:2). Gradually, the Christians became a minority in the Islamic empire. The Muslim authorities favoured a communalistic approach rather than negotiating with individuals. As religious identity was the distinguishing feature of the Christians, the religious leader was seen as the head of the community and given internal autonomy over the group while accepting responsibility for their actions. Under the Ottomans, this became institutionalised as the millet system. In the nineteenth century, the number of recognised denominations increased as some Christians were receptive to Catholic and Protestant missionary efforts. In the case of the Catholic churches, communities had been established much earlier but were unable to obtain official recognition (Maila 1998:36-37).

The Christians in the Middle East cannot be regarded as a monolithic group. They are found in several countries in the region, belong to different denominations and often have multiple identities. In terms of ethnic identity, many would classify 
themselves as Arab. Members of the Greek Orthodox, Greek Catholic and Protestant churches in particular have historically been active in parties and organisations which stress belonging to the Arab nation as the predominant component of their identity. However, others have connected their distinct religious identity to a separate ethnic group. The Armenians are the clearest example of this. Their communal history and heritage as a Christian nation has been maintained throughout the centuries amongst the diaspora. The survivors of the 1915 massacres and forced marches settled in Arab lands (primarily Syria and Lebanon) and added to the existing Armenian communities there (Migliorino 2008). Their desire to preserve their identity through the use of the Armenian language and encouraging marriage from within the community means that to a certain extent they can be categorised as a closed community. However, by having no separatist interests within the region, their different ethnic identity is not perceived as a threat by any government in the states where they are located. It appears that their distinct identity can be acknowledged and respected by state authorities because it is fully compatible with their status as loyal citizens to the countries where they reside. The Assyrians have been less successful in gaining recognition of their claims of a separate ethnicity. Again, a separate language, church and heritage were used to distinguish the community from its Arab neighbours. A failed attempt to create an Assyrian homeland as part of the post-World War One Western division of the Ottoman Empire led to the killings of 1933. Under the independent state of Iraq, religious but not ethnic differences were tolerated and the Assyrians were categorised as Arab Christians alongside other denominations. In post-Saddam Hussein Iraq, Assyrians have commenced reasserting their ethnic identity albeit cautiously given the political, religious and ethnic divisions which have attributed to the violence which afflicts the country (Healey 2010).

Other churches which have a distinct liturgical language e.g. Aramaic, Syriac or Coptic have also offered an opportunity for those who wish to develop an identity separate from the dominant Arab one. For example, there were attempts within the Maronite community in the late nineteenth century to pursue an 'ethnic' identity by claiming ancestry from the Phoenicians (ancient traders off the Lebanese coast) as well as stressing the development of the community in its homeland of Mount Lebanon (Kanaan 2005:51; Kaufmann 2004). Similarly, the same period witnessed claims from some Copts that they were the true Egyptians descended from the Pharaohs (Watson 2000:7). In the Maronite case, the links between the modern Maronites and Phoenicians appear rather dubious and in both cases, critics have argued that these ties are equally applicable to Muslims in these territories due to conversions to Islam from the time of the Arab conquest (Salibi 1988:179; Watson 2000:7). While the 'ethnic' element of these communities is in doubt, there is certainly a deep connection between the Maronite and Coptic churches and their respective homelands - Lebanon and Egypt and this has allowed them to contribute to the nationalist discourse in both countries. In summary, the plurality of Christian identity in the Middle East is demonstrated by the fact that while some correspond directly with an ethnic group whether the dominant Arab or a minority group and others overlap with specific states, these two categories are not necessarily incompatible.

\section{Political Environment and Constraints}

The political participation of Christians in the Middle East must be examined in the context of the tradition of authoritarianism which is prevalent in the region. The identity of the leaders has rarely changed beyond the ruling family during the lifespan 
of younger generations regardless of a republican or monarchical state structure. The protests which erupted in 2011 led to the resignation of Egyptian President Hosni Mubarak of Egypt who had been in power since 1981. Similarly in Syria, the long rule of the Asad family is under threat. Hafez al-Asad was president from 1971 until his death in 2000 when he was succeeded by his son Bashar. In the Hashemite Kingdom of Jordan, most Jordanians have witnessed the reign of two kings - King Hussein (1952-1999) and his son King Abdullah II. While this entrenchment of power is now being challenged, it is apparent that regimes have used a variety of measures to attempt to retain influence. Constitutional arrangements ensure that power is concentrated in the executive including notably the command of the military and security services. Legislative authority is further constrained by adapting electoral laws which dilute the impact of opponents, tight restrictions concerning the formation of political parties, crackdowns on the opposition during electoral campaigns and in some cases, interference on election day including preventing voters from entering polling stations and falsifying votes (Pripstein Posusney 2005:91-92). The weakness of civil society and opposition parties which are often beset with fragmentation, internal infighting and financial difficulties has also detracted from offering alternatives to the existing regimes. While the 1990s onwards saw a move towards regular parliamentary elections and in the case of Egypt, the first presidential elections in 2005, these were not considered as indicators of democratization in the region. In the Egyptian example, the leading opposition candidate Ayman Nour polled only $8 \%$ of votes compared to Mubarak's $88.5 \%$ although it is revealing that only $23 \%$ of the Egyptian electorate actually opted to participate in the election. Nour later found himself arrested and imprisoned for five years over apparent campaigning irregularities (Shahin 2010:106). In Jordan, parliamentary elections were reinstated in 1989 but the regime was integral in shaping electoral mechanisms such as electoral laws and the size of districts as well as dissolving parliament (2001-2003 and 20092010) according to its own interests (Hamid 2010). Such measures demonstrate the difficulties associated with challenging the status quo in the region. As Brown and Shahin note regarding so-called reforms, "All are top-down efforts undertaken to enhance the grip of faltering authoritarian or semi-authoritarian regimes on power' (2010:4). It was not until the 2011 protests that this combination of co-option and repression was significantly challenged by popular uprisings.

Since independence, the Arab states have struggled to make an impression on the multiple challenges facing the region. Domestically, various factors such as socioeconomic inequality, poverty, unemployment, corruption and lack of investment in education, health and social services all hinder the quality of life experienced by many citizens as detailed in successive United Nations Development Programme reports on Arab Human Development (UNDP 2009). These problems are exacerbated by the implications of a population explosion which was estimated in 1980 to be around 150 million region-wide but by 2007 had reached 317 million (UNDP 2009). Furthermore, there is a significant 'youth bulge' in the Arab world with $60 \%$ of the population estimated to be under the age of 25 . In these circumstances, most governments would struggle to dramatically improve the situation but arguably, this places the authoritarian non-oil wealthy Arab regimes in a dilemma. They are unable to placate their populations by 'buying' their acquiescence through providing material goods and instead, have been forced to offer political opening as compensation as occurred in Jordan and Algeria in the late 1980s. Most top-down 'reform' initiatives can be traced back to either economic difficulties or external (usually Western) pressure. The events of 2011 would suggest that such measures have not been 
uniformly successful given the intertwining of economic and political factors such as wealth inequality and corruption which started the initial uprising in Tunisia and then spread to neighbouring countries. Regionally, instability and insecurity remain key concerns for both regimes and their citizens. The Israeli-Palestinian conflict has now been joined by the situation in Iraq as a key grievance in the Arab world. The failure of Arab regimes to successfully resolve these issues whether through peaceful or military means adversely affects their legitimacy. Combined with the Palestinian refugee issue and the regional role of Iran, all of these factors shape the prospects of regional stability which also has a direct impact on the economic and political outlook. Migration from the Arab world is also a common trend. While Lebanon is one of the few Arab states not categorised as authoritarian, unfortunately its regular experiences of unrest connected to both domestic and regional issues means that it still suffers from many of the conditions above. Consequently, it would be accurate to say that these factors are not conducive to encouraging political participation. Such activities can be seen as pointless when it is perceived that the same elite remain in power, difficulties are rarely tackled and security is not guaranteed. Even given the change of governments in Tunisia and Egypt in 2011, it is not yet apparent that the old elite have fully lost their influence. Therefore, when examining Christian political participation in the region, one must be aware of this context which affects all of the population regardless of religious identity.

However, the Islamic environment also adds additional complications for political participation by non-Muslims or Muslim minorities. In the Arab world, religion has in general retained social significance and therefore continues to influence political affairs. In the majority of Arab countries, the role of Islam is recognised in the constitution as the official state religion and sharia is often acknowledged as a source of legislation - to what extent is dependent on each country. The political role of Christians has long been dependent upon interpretations of Prophet Mohammed and subsequent caliphs' perspectives on the position of non-Muslims. Historically, Christians and Jews were categorised by the Muslim conquerors in the seventh century as ahl al-kitab (people of the book) and as such were given the options of converting to Islam, retaining their original faith or continuing to fight. Those who remained Christian or Jewish were free to practice their own religion, had internal autonomy and enjoyed external protection from the Muslim armies in exchange for acknowledging Islamic rule and the payment of taxes known as the jizya. These treaties led to non-Muslims being known as dhimmi (covenanted people) (Scott 2010:16). Throughout the various Islamic empires, individual non-Muslims were able to advance in specific professions such as medicine, administration and scholarship. However, they were subject to discrimination including periodic spells when popular Muslim discontent at their position at court would lead to a backlash against them (Griffith 2005:232-236).

In contemporary Islamic thought, this dilemma has still not been resolved. The right of non-Muslims to worship is generally respected and individuals are able to participate in the state and society. However, it is usually accepted that certain positions are off-limits such as head of state or commander of the army. One function of these roles is to lead Muslims in both temporal and spiritual activity - a role which it is perceived cannot be undertaken by non-Muslims. In some cases, there may be a written restriction e.g. Syria whereas in others, it is seen as a matter of convention. Lebanon is the exception to this case as its process of nationbuilding allowed Christians to play an integral role in the state to the extent that it is guaranteed that the president should belong to the Maronite Christian community. 
Even within the contemporary political Islam current, the extent of participation of non-Muslims is contested. The debate within Islamist circles in Egypt exposes the different perspectives available. While it is mostly accepted that Coptic Christians are citizens, it is disputed to what extent this corresponds to equality (Scott 2010:122). Moving on from statements made in 1997 by the then spiritual guide Mustafa Mashhur that Copts should be excluded from military service and pay jizya as a symbol of their position as dhimmi, the deputy spiritual guide Mohammed Habib affirmed almost ten years later that 'We consider our Coptic brothers as citizens enjoying all the rights associated with citizenship.... We consider them as partners.... The basis for filling public posts shall be efficiency, ability and experience, not religion or beliefs' (Browers 2009:66; Harnisch and Mecham 2009:199). Yet, the tension over the issue of non-Muslim guardianship over Muslims which is viewed as prohibited under sharia ensured that their 2007 draft platform still excluded Christians from attaining the office of presidency (Harnisch and Mecham 2009:199). Following the overthrow of the Mubarak regime, the Muslim Brotherhood has been recognised as the Freedom and Justice Party which is open to non-Muslims as part of the political party regulations. (The Daily Star 2011). The wasatiyya (moderate/centrist) trend has attempted to bridge this gap between Islamic teaching and the need for full citizenship for non-Muslims by promoting a civilization approach. By focusing upon the historical contributions of Christians to Islamic civilization, this pluralist concept of the umma can 'refer to a broader cultural community that includes Egypt's Coptic Christians' (Wickham 2004:209). According to Rafiq Habib a Coptic Protestant intellectual associated with the al-Wasat party, the concept of Islam as a civilization 'encompasses full civic equality for all members of the umma, as citizens of state, regardless of faith' (Browers 2009:68). Furthermore, some Islamist intellectuals have argued that Copts have participated in historical struggles in Egypt and therefore should be perceived as shuraka (co-partners) rather than merely muwatinun (citizens) (Browers 2009:68). Yet, these ideas have failed to garner widespread support among Islamists, the wider Muslim community or indeed Egyptian Christians. Regarding this idea of a shared civilization, Hatina notes that 'Copts viewed it as blurring their distinctive legacy, and Islamists viewed it as detracting from Islam's key role in shaping society and its superiority over other cultures' (Hatina 2006 :49). This ongoing deliberation in Egypt over the political role of non-Muslims highlights the difficulties faced by Christians throughout the Arab world in their attempts to overcome restrictions placed on their activities by Islamic teaching and practice.

\section{Individual Participation}

Given the constraints imposed by a religious oriented environment, it is no surprise that Christians eagerly contributed to an ideological movement which promised participation based on belonging to an Arab nation rather than a particular religion. Christians played a pioneering role in the nahda the mid-nineteenth century literary revival which centred upon Greater Syria. Scholars such as Butros al-Bustani, Nasif al-Yaziji and Khalil al-Khuri contributed to the idea that the Arab nation was founded upon a shared language, culture and history. Similar to the current wasatiyya civilizational approach, it was argued that as Christians could identify with this in the same way as Muslims, they were automatically members of this Arab nation (Jandora 1984:73). Through their involvement in education, literary societies and journals, they were able to help spread these ideas throughout the Arab provinces of the Ottoman Empire in the late nineteenth century and early twentieth. For example in Palestine, Christian journalists were at the forefront of warning the population about 
the dangers of Zionism and stressed the need for an Arab state through newspapers such as al-Karmil (Najib Nassar) and Filastin (Isa al-Isa and Yusuf al-Isa) (Shomali 1995:228-229). Increasing calls for decentralization within the Ottoman Empire led to the politicization of the Arab nationalist movement which intensified as a consequence of the 1908 Young Turks Revolution and the ensuing Turkification process leading to the 1916 Arab Revolt. During this transformation, the place of Islam within the Arab nationalist ideology became prominent. Browers suggests that Arab nationalism in the Maghreb where there were few Christians had always perceived Islam as being a central component whereas in the Mashreq, there was a more secular tendency within early Arab nationalism (Browers 2009:21). While Christians may have perceived ethnicity as being the main element, for many Muslims, Islam could not be separated from Arabism due to its impact on the history of the region and the place of Arabic as the language of the Qur'an. In order to become a populist ideology, Christians had to accept an expansion of the Islamic element and according to Salibi, at least acknowledge the historical role of Muhammad as the founder and leader of both the Arab nation and Islamic civilization (Salibi 1988:48). While Christians were clearly a minority within this populist movement, some individuals were still able to attain prominent positions.

In Egypt, Makram Ebeid Pasha was an influential member of the Wafd party which struggled to gain independence from Britain in the 1919 revolution and then became a major actor in Egyptian politics. Renowned for his legal skills, oration and knowledge of foreign languages, Makram Ebeid was clearly an asset to the burgeoning nationalist party. His involvement in anti-British activities which led to his imprisonment and exile also meant that he was perceived as a loyal nationalist. Makram Ebeid was elected to a predominantly Muslim district of Cairo and held influential positions including Minister of Finance. Similar to other notable Coptic Wafd members, he believed that both Copts and Muslims should unite to attain independence and that this joint struggle guaranteed Copts an equal place in the new Egypt. Therefore, he strongly rejected the idea of parliamentary quotas or classification as a minority group dismissing such measures as British attempts to divide and rule. Throughout his political career, he continually reiterated the bonds between Egypt, its citizens and its religious heritage such as 'I am a Christian, it is true by religion, but through my country, I am a Muslim' (Nisan 1991:122). Yet, the Wafd party failed to satisfy Coptic expectations of equality particularly by the mid1930s. Makram Ebeid's inability to progress beyond the deputy position to become party secretary or Prime Minister was one of the factors which led to his decision to establish a splinter party al-Kutla al-Wafdiyya (Makari 2007:52). While he remains a powerful symbol of Egyptian national unity, his failure to attain the eminent political positions demonstrates the shortcomings of the nationalist approach where religious identity still impacts on the extent of political participation available.

Similarly, Syria presents another example of a prominent Christian activist who was instrumental in the Arab nationalist struggle - this time as a formulator of the ideology. Michel Aflaq, a Greek Orthodox schoolteacher co-founded the Arab Ba'th Socialist Party in the early 1940s together with a Sunni colleague Salah an-Din Bitar. Their vision of an Arab nation was one where the contribution of Islam was in the cultural not religious sphere (van Dam 1996:33). Aflaq comprehended Muhammad as the founder of the Arab nation and Islam as a response to Arab needs at a particular time in history (Haim 1976:62). Therefore, the key tenets were captured in the party slogan 'wahda, hurriyah, ishtirahkiyah' (Unity, Freedom, Socialism) (Hinnebusch 2001:31). The influence of these ideas was momentous given that the Ba'th party 
became the ruling party in Syria (1963-present) and Iraq (1968-2003). However, the movement was also plagued by internal splits between regionalists and nationalists, military and civilian wings. Ba'thist rule did not necessarily correspond to the ideals of its founders and Aflaq also became a victim of internal disunity and relocated to Iraq. Again, Aflaq's example demonstrates that Christians were able to participate in the initial period of the Arab nationalist movement but then struggled to retain their prominence.

The Arab nationalist approach as a strategy for Christian political participation was also compromised by the wider failings of the movement to deliver its postindependence promises of political participation, economic development, Arab unity and the liberation of Palestine. Instead, it became associated with authoritarianism, corruption, wealth inequality, regional rivalries and military failures. These factors were significant in the rise of political Islam as an alternative to the so-called secular Arab nationalist strategy particularly after the 1967 Arab defeat to Israel. In this new environment, Christians tended to pursue two options. Those who were perceived as politicised tended to be amenable to radical leftist parties which still pursued a secular nationalist approach. For example, George Habash established the Popular Front for the Liberation of Palestine (PFLP) in 1967 and a further splinter group the Democratic Front for the Liberation of Palestine (DFLP) was led by Nayef Hawatmeh. Both espoused the use of armed struggle in order to attain their goal of an independent Palestinian state (Aburish 1993:13). The other option was to exchange traditional Arab nationalism for state nationalism which required individuals to prove their loyalty to the ruling regimes and leaders. Individuals from elite families can regularly be found in prominent political positions such as the Boutros Ghalis in Egypt and the Abu Jabers and Muashers in Jordan. In the Lebanese case, Christians were also widely involved in the nationalist movement although this was focused more on disputes within Lebanese Christian nationalism over the raison d'être of Lebanon i.e. as a refuge for Christians or a homeland for all (Kanaan 2005:126-7). The failure to develop a national identity which included all Lebanese confessions meant that this strategy also failed and was partly responsible for the devastating civil war (1975-1990) which diminished Christian (especially Maronite) political predominance in Lebanon. Yet even in this system, notable families such as the Gemayels and Chamouns were also able to have a lasting presence within the system. In conclusion, individual Christians have clearly been able to contribute to nationalist movements whether pan-Arab or state-oriented but the legitimacy problems facing such movements and governments have led either to participants being tainted by their connections to the regime or becoming involved in more radical movements. Neither approach has proved to be one which has encouraged a significant proportion of the Christian communities in the region to follow suit. Furthermore, concerns at the limitations imposed on Christians by the increased public role of Islam in the region have also affected Christians' views on political participation.

\section{Regime Policies Towards Christian Political Participation}

The type and extent of Christian political participation is also interconnected to the policies practiced by each state and in particular, if distinctive strategies are employed with regard to Christians in comparison to other citizens. The first approach perceives Christians as the same/indistinct from the rest of the population in terms of their rights and responsibilities to hold office, stand as candidates and join in political life, In other words, it is possible to attain positions on the basis of competence and 
political views rather than religious identity. There is a direct correlation between this approach and states which publicly portray themselves as 'secular'. When surveying the Syrian example, it is apparent that the 'Alawi dominated regime sought to minimise religious identity within the political arena. Appealing to an inclusive version of Arab nationalism based on a shared heritage and language, would allow individuals from minority groups to participate as Syrians rather than any other subnational identity. This was attained through the vehicle of the Ba'th party. Indeed, President Bashar al-Asad publicly declared that this interpretation of Arabism was a means to incorporate all. 'Arab nationalism is not an ethnicity, it is a cultural feature' (al-Safir 2009). Therefore, under his own presidency and that of his father, Christians have continued to contribute to the political life of the country and can be found in the cabinet, national assembly, Ba'th party and public administration. In a different vein, a small number of Christians can also be found amongst the opposition with individuals such as Michel Kilo and Anwar al-Bunni being imprisoned regularly. In these cases, opponents are targeted due to their attitude towards the party and regime rather than their religious identity.

Yet, even in this so-called secular system, Christian identity is not totally ignored. While Christians serve as cabinet ministers and high-ranking army officers, it is assumed amongst all Syrian society that it would not be appropriate for a Christian to be the head of state. Indeed, Article Three of the constitution declares that the religion of the president must be Islam (International Constitutional Law 2010). Furthermore, there may not be official quotas for the amount of Christians involved in national institutions but regardless, the regime ensures that Christians are nominated to the Ba'th list in regions with a considerable Christian population. Similarly, the cabinet will always have at least one Christian minister. While individuals selected will be known for their political loyalty and competence, it is clear that their religious identity is also significant. These actors are not necessarily expected to represent their respective churches or indeed communities but instead present a visual illustration of the incorporation of different groups within the political system under the banner of Ba'athism. The regime is blatantly aware of Christians' apprehension for their role in society if a change of government took place in Syria. This has become more pronounced as a consequence of the protests which erupted in Syria in mid-2011. Until this point, the suppression of the 1982 Muslim Brotherhood-led revolt and the rise of sectarian violence in post-Ba'thist Iraq were utilised to demonstrate the shared interests of the regime and minorities in Syria. Now, the dangers of sectarian splits appear closer to home. It is far too simplistic to label this as a case of 'minorities sticking together' but clearly the Ba'thist regime does not perceive its Christian citizens as presenting a significant threat and instead has identified their support as useful but not vital. This favourable policy may also be connected to the size of the Christian community in Syria which is estimated to be just below two million, around $8 \%$ of the population. Similarly, Syrian Christians are conscious that governmental acceptance of their right to political participation as Syrian citizens allows them to generally operate within the same parameters as any other Syrian, albeit given the concentration of power in the presidency, these are rather limited. It is noticeable that the Christian community as a whole has been rather silent concerning the unrest taking place in Syria in 2011. The general experience in Syria has contributed to perceptions amongst Christians that Syria is a leading example in the Arab world with regard to their integration into political and societal life but they also implicitly recognise that there are a few extra constraints particularly related to access to high office. To summarise, the Syrian Ba'thist 
version of secularism has enabled Christians to choose to participate in political life yet at the same time, this is not without some recognition of their religious identity which both assists and hinders them in their political aspirations.

The second approach emphasises that Christians are part of the nation and on the basis of being 'loyal citizens' have the right to participate in the political affairs of a country. Countries which have a mixed secular and Muslim heritage within the political and legal systems are likely to support Christian participation but justify this in terms of Christians having secured this right through their patriotism in the past. In contrast to the first category, they are now defined by their religious identity. While individual Christians can be elected or picked to high positions depending on their personal qualities, one overt objective is to ensure Christian presence in the political system. As has been seen in the case of Egypt, the involvement of Coptic Christians in the nationalist movement against the British meant that they were offered and accepted the right to participate in the political system of the independent state as equals and rejected any special provisions for Coptic representation. However, under the republican regime since 1952, Copts have struggled to be elected to parliament and apart from occasional exceptions, rarely attain other highly ranked state positions. In the 2000 parliamentary elections three Copts were elected followed by only one in 2005 - the Minister of Finance Youssef Boutros Ghali who depended on the considerable backing of the National Democratic Party, the ruling party (Shehata 2008:116). Consequently, it became traditional for the president to use some of his ten nominations to the parliament to supplement Coptic representation. Similarly, the cabinet will usually include two Coptic ministers. This low level of representation is contrasted with the size of the Coptic community which although disputed numbers at least five million, around 5-6\% of the population.

In general, the Egyptian political elite do not acknowledge that the political reality has not lived up to the ideals of equal participation regardless of religious identity which was espoused by the early twentieth century Egyptian nationalist movement. Coptic grievances regarding their under-representation in political life, church building legislation and violent communal incidents are not directly addressed. Instead, whenever these issues are raised, the national unity discourse becomes prevalent which affirms that Copts and Muslims make up the Egyptian nation and stresses historical events such as co-operation during the 1919 revolution (McCallum 2010:98-106). For example, President Hosni Mubarak frequently remarked on this unity in public speeches, 'There is no difference between us at all. We are all Egyptians' (al Jazeera 2005). While such responses clearly demonstrate that Copts are to be accepted as part of the Egyptian nation, it can also be interpreted as an indication of opposition to this idea as if it was accepted by all Egyptians, it would not be necessary to have to constantly repeat such sentiments. Thus, these statements do not offer a proactive solution to the underlying causes of communal tension. This is partly because the Mubarak regime was unwilling to risk upsetting the delicate balancing act of allowing a gradual Islamization of society and subsequent political demands while still retaining secular principles which regard all Egyptians as equal. The Egyptian constitution reflects this ambiguity of secular and religious heritage as Article Two proclaims that Islam is the state religion and sharia is the principal source of legislation while Article Forty states that there is no difference between citizens based upon religious (or other) identities. This apparent contradiction and the refusal of the government to address it can be connected to the primary goal of stability. These are contributory factors to the growing Coptic withdrawal from the Egyptian national political system. 
There is a general consensus within the Coptic community that it is futile to attempt to work within this system. Coptic politicians are not perceived as prioritising campaigns on concerns raised by the community such as communal violence, discriminatory legislation and the implications of an increasingly Islamic public sphere. Instead, they are frequently dismissed as Christians in name only who have little interest in the actual community. As they are often connected to the ruling elite and several come from the traditional Coptic elite families, it is assumed that they will be beholden only to those who propelled them to these positions. Dissatisfaction with this type of representation has allowed the religious leadership of the community through the dominant Coptic Orthodox Church to establish its own credentials as spokesman and liaison between the government and the community (McCallum 2010:123-158). These are the challenges faced by the post-Mubarak rulers of Egypt (currently the army). While some Copts were actively involved in the 2011 protests and perceived the campaign for democracy as a means of readdressing citizenship issues, the continuance of communal violence suggests that the underlying issues relating to equality still need to be resolved. Therefore, the Egyptian case study highlights that the 'loyal citizen' strategy is supportive of Christian political participation but with the understanding that preserving stability will always be prioritised over resolving the dilemma between national and religious identity. For Christians, this approach does not appear to deliver the conditions required for their full and equal political participation. Instead, any involvement in national affairs has to be embarked upon under the same rules for all Egyptians while simultaneously, it is acknowledged that they are different from the majority, thus casting doubt on whether they can be treated equally in these circumstances.

The third strategy recognises the differences between citizens by institutionalising these through the political system. This is usually attained through the use of quotas for minority groups to ensure their representation in parliament. This system is more likely to take place in countries where the Christian community is numerically marginal both in terms of actual numbers and percentage of the overall population. It is argued that without quotas, they would struggle to attain representation. In some cases, such an approach may also be prevalent in states where Islam is ascribed a significant place in the political system. Jordan, Iraq and the Palestinian Authority all offer illustrations of this policy. The starting point would appear to be that the governing elite wish to safeguard minority representation within parliament and believe that this must be guaranteed through a quota system. Christians as a religious minority are deemed eligible for this assistance. In Jordan, Christians are allocated nine parliamentary seats along with three Circassian/Chechen seats and twelve seats reserved for women. In 2010, one of these seats was won by a Christian bringing the total Christian representation in parliament to ten (Jordan Times 2010). Similarly in post-Saddam Hussein Iraq, Christians have been assigned five out of the eight seats for minorities while a $25 \%$ quota for female parliamentarians has also been introduced (POGAR: 2010). Finally, since the first elections held in 1996, the Palestinian Authority parliamentary electoral law has included six guaranteed Christian seats and one Samaritan seat in areas where these groups are numerous (Central Elections Commission Palestine n.d.)

In these examples, Christians have not been singled out and instead, the quota approach is justified by the state authorities as a means to ensure representation of groups within society who would otherwise be marginalised either due to their small numbers or societal traditions. It would appear that there is an underlying assumption that without this assistance, the Arab Muslim majority would be unlikely 
to elect these marginal groups whether their distinction is due to religious identity, ethnicity or gender. Some influential individuals would possibly succeed but in institutionalising representation, a set amount is guaranteed. In determining how these seats are divided, the Jordanian electoral law divides the country into regionalbased constituencies and the Christian seats are located within regions with a significant Christian population. While ensuring nine Christian parliamentarians, in another way, the law theoretically restricts representation. If the second-placed Christian candidate was to poll more than the last candidate to win the Muslim seats, this individual would still not be elected (unless eligible to win through the women's quota). However, the Jordanian system allows the over-representation of Christians in parliament since they are given $7.5 \%$ of seats while estimates suggest that they are no more than $4 \%$ of the population (Jordan Times 2010). The 2009 Iraqi electoral law amendment meant that Iraq adopted a similar path as Jordan by introducing quotas for women and compensatory seats for minorities. As the Christians make up the largest of these minorities, they are guaranteed five seats. This contrasts with the previous election in 2006 when only one Christian candidate was successful through a compensatory seat. However, Iraq diverges from Jordan in the sense that the Iraqi parliament is much larger and therefore, in terms of percentage of seats, they have only $0.2 \%$ compared to their estimated population of 3\% (al Jazeera 2010). In the Palestinian Territories, the quota system was incorporated into the Basic Law (constitution) of the Palestinian Authority and includes six Christian seats in areas with a significant Christian population. Christians are still able to stand through the normal process and some prominent individuals have been successful through this approach notably the academic and politician Hanan Ashrawi. Such accomplishments prove that it is possible for Christians to win parliamentary seats without additional help but it would perhaps be difficult to regularly find candidates with this public recognition. Hence, the legislation serves as a guarantee of securing Christian representation within parliament.

As has been demonstrated in previous sections, political participation is not solely confined to representation within parliament. Given the lack of power and influence of most parliaments in the Arab world, the ability to participate in political life beyond these institutions is important if a group is to have any sway over decisions. In Jordan, cabinets usually include two ministers and Christians can also be found as palace advisers, in senior ranks of the military and in high positions within public administration. Within the Palestinian Authority, individual Christians have been prominent as presidential advisers and within government ministries. In Iraq, one Christian was appointed to the thirty-two strong cabinet in 2005.

In institutionalising the differences between the Muslim majority and a Christian minority, this quota approach highlights the significant role of Islam in the political system. All three case studies acknowledge Islam as the official state religion and sharia as a source of legislation. They also include references to equality before the law and freedom of worship but once more, the contradiction is clear. Indeed, Iraqi Christians contested the drafting of the constitution in 2005 over its reference to the Islamic identity of Iraq (Yacoub 2008: 93-94). This perception of Islam as the common factor which binds the nation together would appear to be more pronounced than in Syria and Egypt. This can partly be attributed to the small size of the communities with around 240,000 (4\%) in Jordan, 7-800,000 (3\%) in Iraq and 50,000 $(2 \%)$ in the West Bank. The quota system can also be interpreted as conveying to the communities that the regimes are not willing to leave their representation to chance but instead have chosen to guarantee their political presence. In the Iraqi case, 
internal commitment to this policy can be questioned given the debates surrounding minority seats in provincial and national elections and the current system can certainly be traced to the circumstances surrounding the post-Ba'thist nationbuilding project. However, given that the three main groups in Iraq (Shia, Sunnis and Kurds) are struggling to divide power, it is not surprising that the political participation of small minorities such as Christians, Yazidis, Shabaks and Mandaeans are not regarded as a priority by the political elite. In contrast, the Jordanian and Palestinian elites have clearly stated their desire to ensure representation of their pluralist societies. In affirming the contribution of Christians to the nation, the differences may be institutionalised but the national attachment of the community is acknowledged.

Furthermore, the quota approach has the potential to allow access to the political arena to candidates supported by the community. In general, these figures still tend to be linked to the ruling elite but individuals affiliated to leftist parties have also been successful. As in the other case studies, Christian politicians are rarely seen as representing only 'Christian issues' and instead are active on wider political, economic and social matters. However, this does not seem to elicit the resentment seen in Egypt which is perhaps indicative of the lack of communal violence in Jordan and the Palestinian Territories. In contrast, Iraqi Christian politicians have become associated with voicing the concerns of the community to the government. This aspect has been heightened by the accentuation of Assyrian ethnic identity as opposed to the Arab identity imposed under the Ba'th regime when the most prominent Christian political actor Tariq Aziz was perceived as first and foremost a Ba'thist with little interest in representing Christians. Possibly as a reaction to this, several Christian political parties have been established including the Assyrian Democratic Movement and the Chaldean Syriac Assyrian Popular Council (POGAR 2010). Therefore, depending on conditions within the state, the quota system can not only ensure that the community contributes to the selection of candidates but also provide them with the opportunity to represent key issues, thus heightening differences from the majority.

The last example of a quota system diverges from the above examples as the political system is based solely on quotas. The Lebanese confessional system allocates parliamentary seats, cabinet members and government ministries according to the demographic composition of the country. Originally based on the 1932 census, this arrangement was adjusted in the 1989 Taif Accord to allow parity between Muslims and Christians. As this system applies to all Lebanese groups, the Christian communities are not treated differently from any other. Indeed, it can be argued that Christians benefit from the confessional system as it is estimated that the largest Christian denomination - the Maronites - make up around $22 \%$ of the population (Faour 2007:917). Unsurprisingly, Christians are generally strong supporters of maintaining this political system arguing that it is the best option for a highly divided society. The issue of deconfessionalism has been raised by other actors during times of crisis but serious pressure to achieve this has not occurred despite its mention in the preamble to the constitution. While Christians may enjoy substantial representation in political life, this has not prevented alienation of the communities from the elite. This is particularly true of the Maronites. During the years of Syrian dominance after the Taif Accord, electoral discrimination was common against anti-Syrian opponents who were primarily though not solely Christian (McCallum 2010:106-110). The individuals in prominent positions such as the presidency and cabinet were regarded as Syrian-approved appointments and were not seen as representative of the community. This was in sharp contrast to the other two main communities who 
enjoyed either strong individual leadership e.g. the Sunni Rafiq al-Hariri or influential political organisations e.g. the Shia-dominated Amal and Hizb'allah groups. The 'Cedar Revolution' in 2005 allowed the two main Maronite leaders Michel Aoun and Samir Geagea to return from exile and prison respectively and re-enter politics. Yet, they proved too divisive to challenge for the presidency in 2007-2008 leading to the eventual appointment of the former army commander Michel Sleiman. Maronite discontent remains due to chronic instability and the perception that politicians remain more interested in personal gain than improving conditions for their constituents. It is important to note that this is shared by members of other communities. As well as being vulnerable to political manipulation, the Lebanese quota system also clearly accentuates religious identity as the basis of political representation which adversely affects national identity. Lebanese politics since 2005 have been based on SunniShia divisions. The presence of Christian politicians in both political factions (March $14^{\text {th }}$ and March $8^{\text {th }}$ ) has arguably helped to reduce the danger of confessional conflict but has also demonstrated political disunity within the community. In this example, Christians have been treated similarly as other groups through a quota system but this is directly linked to what can be termed Lebanese exceptionalism with regard to the make-up of the population and the ensuing political system.

\section{Conclusion}

In examining the nature and extent of Christian political participation in the Arab world, it is apparent that this cannot be analysed separately from the wider political situation in the region. The prevalence of authoritarian regimes has meant that political participation has predominantly been defined by the ruling elite. This refers to both the identity of the participants and the parameters of their activities. The general disconnection between the state and its citizens has been experienced by Muslims and Christians alike. Yet, while there is obvious discontent with approaches towards inclusion, Christians are also concerned at a change in the status quo which may increase the public role of Islam further at the expense of the political rights of non-Muslims. Therefore, the impact of the 2011 Arab Spring is being watched warily by Christians (amongst others) in the region. Recent efforts have been made to reconcile Islamic teachings with the demands of equality which are inherent in Christian understandings of involvement in national politics but it has proved considerably difficult to bridge these differences. This is particularly true regarding the issue of non-Muslim rule over Muslims and the significance of Islam being recognised as the official state religion. The continued existence of both written and de facto limitations on Christians gaining access to high political office serve as a constant reminder that the 'equality' espoused in constitutions, legislation and speeches on national unity usually comes with certain restrictions. While the nationalism of the early and mid-twentieth centuries initially offered individual Christians an opportunity to participate as equal citizens, the failure of this ideological approach to negate religious identity in the political sphere meant that rhetoric may still talk of political equality but reality is rather more ambiguous. The attention shown by various states to have visible examples of their inclusive nature through the formation of cabinets and legislatures has the potential to be perceived by Christians as demonstrating tolerance of their political participation rather than acknowledging their rights as citizens to have a stake in national affairs.

This paper has explored three strategies towards Christian political participation. In all three, religious identity has proved crucial. Officially, Christians in Syria are treated as indistinct from other Syrians as part of the secular nature of the Syrian state 
but in reality, the regime ensures that this sector of society is represented at all levels of the political sphere. In Egypt, Christians are identified as 'loyal' citizens as part of a justification of their involvement in political and societal issues. As they struggle to gain representation under existing rules, their political presence is boosted by presidential intervention. Therefore, it would seem that attempts to avoid official acknowledgement that religious identity does affect the ability of Christians to play a full role in the political system merely lead to behind the scenes efforts to redress this imbalance. The institutionalization of differences appears to be the most common strategy. This approach has the advantage of securing representation and illustrating acceptance of the role of Christians. However, it also places limitations on the amount of representation and overtly prioritises sub-state identities in determining the type of access that can be attained in the political sphere. While such initiatives may be justified by states as benevolence towards a particular sector of society which would otherwise struggle to attain representation, they also have the potential to divide the population into different categories of citizenship. By introducing different rules for citizens according to their identity, it can be argued that the Arab states erode the credibility of their claims of national unity where all citizens are equal. Yet, there is also self-awareness amongst some Christian communities that this limited role may prove more inclusive than alternatives to existing regimes. Developments in Egypt after the fall of the Mubarak regime in early 2011 are being closely scrutinised by Christians both in Egypt and the wider region. Naturally, there is strong interest in how the new government approaches the complex issue of Christian political participation. Will they follow current policy, choose one of the other existing strategies or admittedly unlikely perhaps develop a more ambitious approach which directly tackles the question of full equality and citizenship for Christians?

In conclusion, the strategies outlined above demonstrate that religious identity remains a crucial component in determining how regimes deal with their Christian citizens. Clearly, a glass ceiling exists in terms of Christian access to political power. The ability and desire of regimes to convince Christians that they are incorporated as equal rather than tolerated citizens appears connected to regime legitimacy. The evidence suggests that regimes are unlikely to fully address this controversial issue given that it would necessitate the opening up of the debate on the public role of Islam and thus threaten regime stability. Instead, Christians will be allocated a role in the political system - one which illustrates their presence but provides constraints to their influence, thus highlighting that religious difference still matters irrespective of the extent of national unity rhetoric. 


\section{References}

Aburish, S K. 1993. The Forgotten Faithful: The Christians of the Holy Land. London: Quartet Books Limited.

Browers, M L. 2009. Political Ideology in the Arab World: Accommodation and Transformation. Cambridge: Cambridge University Press.

Brown, N. and Shahin, E. ed. 2010. The Struggle over Democracy in the Middle East. Abingdon: Routledge.

Central Elections Commission Palestine, The Palestinian Electoral System n.d. www.elections.ps/template.aspx?id=33 Accessed 10th November 2010

Courbage, Y. and Fargues, P. 1994. Christians and Jews under Islam. London: IB Tauris.

The Daily Star, Egypt's Muslim Brotherhood legalized as party 7th June 2011 http://www.dailystar.com.lb/id=140605 Accessed 7th June 2011

van Dam, N. 1996. The Struggle for Power in Syria: Politics and Society Under Asad and the Ba'th Party. London: Croom Helm Publishers Ltd.

Egypt's Government Services, Egyptian Constitution. 22nd May 1980 http://www.egypt.gov.eg/english/laws/constitution/default.aspx Accessed 10th November 2010

Faour, M. 2007. Religion, Demography, and Politics in Lebanon. Middle Eastern Studies 43(6): 909-922.

Griffith, S. 2005. The Eastern Christians and the Muslims: the Past as Prelude to the Present. Bulletin of the Royal Institute for Inter-Faith Studies 7(2): 225-242.

Haim, S.G. 1976. Arab Nationalism: An Anthology. Los Angeles: University of California Press.

Hamid, S. 2010. Jordan: the myth of the democratizing monarchy. In The Struggle over Democracy in the Middle East, ed. N. Brown and E. Shahin, 121-133. Abingdon: Routledge.

Harnisch, C and Mecham, Q. 2009. Democratic Ideology in Islamist Opposition? The Muslim Brotherhood's 'Civil State'. Middle Eastern Studies 45(2): 189-205.

Hatina, M. 2006. In Search of Authenticity: A Coptic Perception. Middle Eastern Studies 42(1): 49-66.

Healey, J. 2010. The Church across the border: the Church of the East and its Chaldean branch. In Eastern Christianity in the Modern Middle East, ed. A. O'Mahony and E. Loosley, 41-55. London: Routledge.

Hinnebusch, R A. 2001. Syria: revolution from above. London: Routledge.

International Constitutional Law Project, Constitution of the Syrian Arab Republic. 13th March 1973 http://www.servat.unibe.ch/icl/sy00000.html Accessed 10th November 2010

Jandora, J. W. 1984. Butrus al-Bustani, Arab consciousness, and Arabic revival. Muslim World 74(2): 71-84.

al-Jazeera, Iraq Election 2010. 3rd March 2010

http://english.aljazeera.net/focus/iraqelection2010/2010/03/20103244723763210.html Accessed 10th November 2010

al-Jazeera, Mubarak urges Christian-Muslim unity. 10th January 2005 www.aljazeerah/MubarakUrgesChristianMuslimUnity.html Accessed 17th January 2005

Jordan Times, Final results of Tuesday's parliamentary elections. 11th November 2010 http://www.jordantimes.com/index.php?news=31761 Accessed 11th November 2010 
Kanaan, C. B. 2005. Lebanon 1860-1960: A Century of Myth and Politics. London: Saqi Books.

Kaufmann, A. 2004. Reviving Phonecia: The Search for Identity in Lebanon. London: IB Tauris.

Maila, J. 1998. The Arab Christians: From the Eastern Question to the Recent Political situation of the Minorities. In Christian Communities in the Arab Middle East: the Challenge of the Future, ed. A. Pacini, 25-47. Oxford: Clarendon Press.

Makari, P. E. 2007. Conflict \& Cooperation: Christian-Muslim Relations in Contemporary Egypt. Syracruse: Syracruse University Press.

McCallum, F. 2010. Christian Religious Leadership in the Middle East: The Political Role of the Patriarch. Lewiston: Edwin Mellen Press.

Migliorino, N. 2008. (Re)constructing Armenia in Lebanon and Syria: Ethno-Cultural Diversity and the State in the Aftermath of a refugee crisis. Oxford: Berghahn Books.

Nisan, M. 1991. Minorities in the Middle East: A History of Struggle and SelfExpression. London: McFarland \& Company.

Pripstein Posusney, M. 2005. Multiparty Elections in the Arab World. In Authoritarianism in the Middle East: Regimes and Resistance, ed. M. Pripstein Posusney and M. Penner Angrist, 91-118. London: Lynne Rienner Publishers.

Programme on Governance in the Arab Region, Iraq Parliamentary Elections. 7th March 2010

http://www.undp/pogar.org/publications/elections/coverage/legislative/iraq-2010e.pdf Accessed 10th November 2010

al-Safir, Full interview with Syrian President Bashar al-Asad. 30th March 2009 http://www.mideastwire.com/index.php?action-ar2009\#29072 Accessed 8th February 2010

Salibi, K. 1988. A House of Many Mansions: A History of Lebanon Reconsidered. London: IB Tauris.

Scott, R.M. 2010. The Challenge of Political Islam: Non-Muslims and the Egyptian State. Stanford: Stanford University Press.

Shahin, E. 2010. Democratic transformation in Egypt: controlled reforms ... frustrated hopes. In The Struggle over Democracy in the Middle East, ed. N. Brown and E. Shahin, 102-122. Abingdon: Routledge.

Shehata, S. 2008. Inside an Egyptian Parliamentary Campaign. In Political Participation in the Middle East, ed. E. Lust-Okar and S. Zerhouni, 95-120. London: Lynne Rienner Publishers.

Shomali, Q. 1995. Palestinian Christians: Politics, Press and Religious Identity 19001948. In The Christian Heritage in the Holy Land, ed. A. O'Mahony, G. Gunner and K. Hintlian, 225-236. London: Scorpion Cavendish Ltd.

United Nations Development Programme, Arab States Human Development Reports 2009 http://hdr.undp.org Accessed 8th March 2010

Watson, J. H. 2000. Among the Copts. Brighton: Sussex Academic Press.

Wickham, C. R. 2004. The Path to Moderation: Strategy and learning in the formation of Egypt's Wasat Party. Comparative Politics 36(2): 205-228.

Yacoub, J. 2008. La Marginalisation des Chrétiens d'Irak. Confluences Méditerranée 66(2): 83-98. 